\title{
Correction: Identify factors affecting foreign direct investment capital in the southern key economic region
}

\author{
Tran Thi Kim Dao ${ }^{*}$, Nguyen Van Luan
}

Use your smartphone to scan this

QR code and download this article

\section{CORRECTION}

Article "Identify Factors Affecting Foreign Direct Investment Capital In The Southern Key Economic Region" ${ }^{1}$ (DOI: https://doi.org/10.32508/stdj.v22i2.1051) by Tran Thi Kim Dao, Nguyen Van Luan is added the acknowledgement section as below:

ACKNOWLEDGEMENT

"This research is funded by Vietnam National University Ho Chi Minh City (VNU-HCM) under grant number C2019-34-02".

\section{COMPETING INTERESTS}

The authors declare that they have no conflicts of interest.

\section{REFERENCES}

1. Dao, T. T. K., \& Van Luan, N. (2019). Identify Factors Affecting Foreign Direct Investment Capital In The Southern Key Economic Region Science and Technology Development Journal, 22(2), 275-288.
University of Economics and Law, Vietnam National University - Ho Chi Minh City, Vietnam

Correspondence

Tran Thi Kim Dao, University of Economics and Law, Vietnam National University - Ho Chi Minh City, Vietnam

Email:daottk@uel.edu.vn

History

- Received: 2020-08-12

- Accepted: 2020-08-21

- Published: 2020-09-30

DOI : 10.32508/stdj.v23i3.2433

\section{Check for updates}

Copyright

(-) VNU-HCM Press. This is an openaccess article distributed under the terms of the Creative Commons Attribution 4.0 International license.

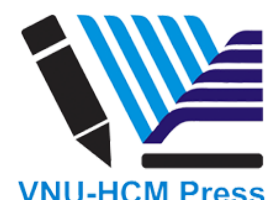

Cite this article : Thi Kim Dao T, Van Luan N. Correction: Identify factors affecting foreign direct in-vestment capital in the southern key economic region. Sci. Tech. Dev. J.; 23(3):720. 